\title{
Recovery of Active Polyphenol Oxidase and Peroxidase from Plant Tissues with High Phenolics and Chlorophylls
}

\author{
Sarana Rose Sommano* \\ Plant Bioactive Compound Laboratory (BAC), Department of Plant and Soil Sciences, Faculty of Agriculture, \\ Chiang Mai University, Chiang Mai 50200, Thailand; sarana.s@cmu.ac.th \\ * Correspondence: sarana.s@cmu.ac.th; Tel.: +66-53-944-040
}

\begin{abstract}
The present protocol described extraction of active polyphenol oxidase and peroxidase from a plant rich in phenolics and chlorophylls in the post-harvest browning syndrome of $B$. myrtifolia. Initially, general optimisation using conventional enzyme extractions was performed. However, along with membrane-bound proteins, chlorophylls and phenols were also released with Triton X (TTX). With a view to obtaining high enzymatic activity, removal of the released chlorophylls and phenols by formation of TTX-114 micelles in the detergent rich phase after hightemperature induced phase separation was tested.
\end{abstract}

Keywords: latent PPO; optimisation; peripheral membrane POD; total phenol content

\section{Introduction}

Backhousia myrtifolia (Cinnamon myrtle) is a native Australian plant cultivated for its cut flowers. Harvested stems bearing clusters of small flowers with white to lime-green sepals are used in flower arrangements as filler flowers. However, extensive flower and leaf browning has become a problem for this novel product. The pre and postharvest browning syndrome [1-3] leaves a lasting loss of confidence within its market places, mainly in Japan [4,5]. Browning in plant tissues high in phenolic content, like B. myrtifolia, is typically the result of enzymatic browning reactions.

Polyphenol oxidase (PPO) and peroxidase (POD) are key enzymes involving post-harvest browning disorder of horticultural produce [6-8]. Their latent stage together with high content of endogenous phenolic compounds and chlorophylls largely interfere enzymatic activity studied $[9,10]$. To overcome this problem, samples were extracted with different phenol removing agents in sodium phosphate buffer ( $\mathrm{pH}$ 6.8) [9]. PPO was activated by the addition of detergents (e.g. TritonX-100) and POD was extracted with mild treatments (e.g. sucrose solution). For partial enzyme purification, high temperature induced phase separation was used. The inclusion of $5 \%$ polyvinylpolypyrrolidone (PVPP) in the extraction buffer was effective in removing polyphenols. Latent PPO in crude extract from B. myrtifolia leaves was activated using $2 \% \mathrm{v} / \mathrm{v}$ TTX-114, resulting in an almost 30-fold increase in activity [9-11]. The same optimised extraction protocol also improved POD activity. While the phase separation step improved enzyme activity, it failed to maintain total protein content. Fresh extract of B. myrtifolia leaf tissue was, therefore, initially concentrated by filtering with an Amicon ${ }^{\circledR}$ PL-10 unit. However, concentrated endogenous phenolics interfered with enzyme activity [9]. 


\section{Experimental Design}

This protocol was conducted towards characterising PPO and POD in the post-harvest browning syndrome of Backhousia myrtifolia, an Australian native ornamental plant cultivated for cut flower production. Leaf and floral tissues of this particular species are known for high phenolic and chlorophyll contents which is the interferences for enzymatic analyses. Initially, general optimisation using conventional enzyme extractions was performed. However, along with membrane-bound proteins, chlorophylls and phenols were also released with TTX. With a view to obtaining high enzymatic activity, removal of the released chlorophylls and phenols by formation of TTX-114 micelles in the detergent rich phase after high-temperature induced phase separation was tested.

\subsection{Materials}

- Polyvinylpolypyrrolidone (PVPP)

- Polyethylene glycol (PEG)

- Sodium phosphate buffer, $0.1 \mathrm{M}$

- TritonX-114 (TTX)

- Bio-Rad protein assay kit with Bovine Serum Albumin (BSA) (Manufacturer's name, city, state if applicable, country)

- 4-methylcatechol (4-MC)

- Hydrogen peroxide $\left(\mathrm{H}_{2} \mathrm{O}_{2}\right)$

- Guaiacol

- NativePAGE ${ }^{\mathrm{TM}}$ running buffer

- Calcium chloride $\left(\mathrm{CaCl}_{2}\right)$

- Ethylenediaminetetraacetic acid (EDTA)

- Boric acid

- Tris

\subsection{Equipment}

- $\quad$ Amicon $^{\circledR}$ ultra unit (PL-10, Milipore, USA).

- Spectrophotometer (Pharmacia LKB-Utrospec III)

- XCellsureLock ${ }^{\mathrm{TM}}$ Mini-cell electrophoresis (Invitrogen ${ }^{\mathrm{TM}}$, Canada)

- Pre-cast NativePAGE ${ }^{\mathrm{Tm}}$ Novex $^{\circledR 3}-12 \%$ Bis-Tris gel (1.0 mm, 10 well)

\section{Procedure}

\subsection{Extraction and partial purification of the enzymes}

Extraction was performed on $1.0 \mathrm{~g}$ samples ground in a mortar and a pestle with $5.0 \mathrm{~mL}$ of various concentration of PVPP or polyethylene glycol (PEG) saturated overnight in $0.1 \mathrm{M}$ sodium phosphate buffer ( $\mathrm{pH} 6.8$ ). The extracts were centrifuged at $10,000 \times \mathrm{g}$ for $25 \mathrm{~min}$ at $4^{\circ} \mathrm{C}$ and the supernatant used to analyse enzymatic activity and total phenolic content. It was found that incorporation of $5 \%(\mathrm{w} / \mathrm{v})$ PVPP in the phosphate buffer removed most phenolic compounds and therefore, it was used for subsequent studies. By adding 2\% (v/v) TTX-114 with the chosen phenol absorbing ager, the highest enzymatic activity was achieved. The rational for this is that latent or integral membrane proteins such as PPO require detergents to activate or loose from the membrane during extraction [12-14]. Further purification by temperature-induce phase separation with TTX114 was as follows:

1. The supernatant was removed to a fresh tube and TTX-114 was added to a final concentration of $8 \%(\mathrm{v} / \mathrm{v})$. 
2. The solution was kept at $4^{\circ} \mathrm{C}$ for $15 \mathrm{~min}$ and then transferred to a water bath at $30^{\circ} \mathrm{C}$ for $10 \mathrm{~min}$. The solution became cloudy due to the formation of large mixed micelles of detergent, hydrophobic proteins, and chlorophylls $[15,16]$.

3. This solution was centrifuged at $5,000 \times g$ for $15 \mathrm{~min}$ at room temperature. The clear supernatant was used to measure both PPO and POD enzyme activity.

\subsection{Protein extraction for electrophoresis studies}

To improve the yield of protein with a view to maximising enzymatic activity of the extracts, the extracts were filtered through an Amicon ${ }^{\circledR}$ ultra unit. Ten millilitres of the extracts was pipetted into a filter unit chamber, capped and then centrifuged at $4^{\circ} \mathrm{C}$ and 5,000 $\times g$ for $10 \mathrm{~min}$. The retentate $(\sim 5 \mathrm{~mL})$ remaining in the filter chamber and the eluate $(\sim 5 \mathrm{~mL})$ in the receiving chamber were tested for enzymatic activity and protein content. Protein content was also determined spectrophotometrically using the Bio-Rad protein assay kit as a standard [17]. Enzymatic activity assays were carried as described herein.

1. The extract $(100 \mu \mathrm{L})$ was added into a $1 \mathrm{~cm}$ semi-micro cuvette containing $250 \mu \mathrm{L} 10 \mathrm{mM}$ 4-methylcatechol (4-MC) solution and $650 \mu \mathrm{L} 100 \mathrm{mM}$ sodium phosphate buffer at $\mathrm{pH}$ 6.8 \{adapted from Jiang [18] \}.

2. After mixing, the cuvette was immediately transferred into the spectrophotometer and absorbance at $410 \mathrm{~nm}$ was recorded every $30 \mathrm{~s}$ for $3 \mathrm{~min}$ at room temperature.

3. An increase in absorbance indicated the formation of brown pigment (o-quinone). PPO activity was calculated as the slope of absorbance against time [19].

4. Similarly, POD activity was measured by adding $100 \mu \mathrm{L}$ of the extract into a mixture of $500 \mu \mathrm{L}$ sodium phosphate buffer (200 mM, pH 5.8), $200 \mu \mathrm{L}$ of $350 \mathrm{mM}$ hydrogen peroxide $\left(\mathrm{H}_{2} \mathrm{O}_{2}\right)$ and $200 \mu \mathrm{L} 2 \mathrm{mM}$ guaiacol \{adapted from Dann and Deverall [20]\}.

5. The increase in absorbance was recorded at $470 \mathrm{~nm}$ at room temperature for $3 \mathrm{~min}$.

6. The reaction assay with $200 \mu \mathrm{L}$ deionised water instead of $\mathrm{H}_{2} \mathrm{O}_{2}$ was also analysed.

7. POD activity was calculated by subtracting the activity without $\mathrm{H}_{2} \mathrm{O}_{2}$ (PPO activity) from the activity with $\mathrm{H}_{2} \mathrm{O}_{2}$ [21].

8. One unit of activity was defined as the amount of enzyme that caused a change in absorbance of 0.001 units per min.

\subsection{Native gel electrophoresis for PPO and POD activity}

1. Non-denaturing gel electrophoresis (native) of protein extract was performed with the XCellsureLock ${ }^{\mathrm{TM}}$ Mini-cell electrophoresis and the following protocol was followed:

2. Samples $(\sim 10 \mu \mathrm{g})$ were loaded into Pre-cast NativePAGE ${ }^{\mathrm{TM}}$ Novex $^{\circledR 3}-12 \%$ Bis-Tris gel (1.0 $\mathrm{mm}, 10$ well) and electrophoresed using the NativePAGE ${ }^{\mathrm{TM}}$ running buffer.

3. The gels were run at $150 \mathrm{~V}$ constantly for $115 \mathrm{~min}$ at room temperature.

4. The native polyacrylamide gels were stained for PPO activity by immersion in $0.1 \mathrm{M}$ catechol solution containing $1.5 \mathrm{~g} \mathrm{CaCl}_{2}, 0.2 \mathrm{~g}$ EDTA, $0.15 \mathrm{~g}$ boric acid and $2.0 \mathrm{~g}$ Tris for $15 \mathrm{~min}$. 
5. The same gels were then incubated in $100 \mathrm{mM} \mathrm{H}_{2} \mathrm{O}_{2}$ for a further $15 \mathrm{~min}$ for POD activity [22-23].

\section{Expected Results}

PPO and POD from B. myrtifolia leaf and floral tissues were recoveries during the extraction with different phenol removing agents in sodium phosphate buffer ( $\mathrm{pH}$ 6.8). PPO was activated by the addition of detergents (e.g. TritonX-114) and POD was extracted with mild treatments (e.g. sucrose solution). For partial enzyme purification, high temperature induced phase separation was used. The inclusion of 5\% polyvinylpolypyrrolidone (PVPP) in the extraction buffer was effective in removing polyphenols (Table 1).

Table 1. Total phenolic concentrations in crude extracts for B. myrtifolia leaves using various

\begin{tabular}{|c|c|c|}
\hline Extraction & $\begin{array}{l}\text { Total phenolics } \\
\text { (mg/g FW GAE) }\end{array}$ & $\pm \mathrm{SE}$ \\
\hline 95\% methanol & 48.4 & 0.02 \\
\hline Phosphate buffera & 40.3 & 0.09 \\
\hline Phosphate buffer $+1 \%$ PVPP & 23.7 & 0.14 \\
\hline Phosphate buffer $+5 \%$ PVPP & 11.0 & 0.06 \\
\hline Phosphate buffer $+1 \%$ PEG & 21.0 & 0.38 \\
\hline Phosphate buffer $+5 \%$ PEG & 21.2 & 0.27 \\
\hline
\end{tabular}

\footnotetext{
As presented in Sommano [9]

a0.1 M sodium phosphate buffer $\mathrm{pH}$ 6.8.

Values are means $(n=3) \pm$ standard error $(\mathrm{SE})$.
}

Latent PPO in crude extract from B. myrtifolia leaves was activated using 2\% v / v TTX-114, resulting in an almost 30-fold increase in activity. The same optimised extraction protocol also improved POD activity (Table 2). While the phase separation step improved enzyme activity, it failed to maintain total protein content. Fresh extract of B. myrtifolia leaf tissue was, therefore, initially concentrated by filtering with an Amicon ${ }^{\circledR}$ PL-10 unit. However, concentrated endogenous phenolics interfered with enzyme activity (Table 3).

Table 2. Effect of detergents and mild extractants on leaf PPO and POD activity for B. myrtifolia leaves.

\begin{tabular}{cccc}
\hline $\begin{array}{c}\text { Phosphate buffer } \mathrm{pH} \\
\text { Agent }\end{array}$ & $\begin{array}{c}\text { Phenol absorbing } \\
\text { mild treatments }\end{array}$ & Enzymatic activity (units/ mL) \\
\hline PPO activity & $5 \%(\mathrm{w} / \mathrm{v}) \mathrm{PVPP}$ & none & $7.67 \pm 0.3$ \\
$\mathrm{pH} 6.8$ & $5 \%(\mathrm{w} / \mathrm{v}) \mathrm{PVPP}$ & $1 \%(\mathrm{w} / \mathrm{v}) \mathrm{SDS}$ & $10.0 \pm 1.7$
\end{tabular}




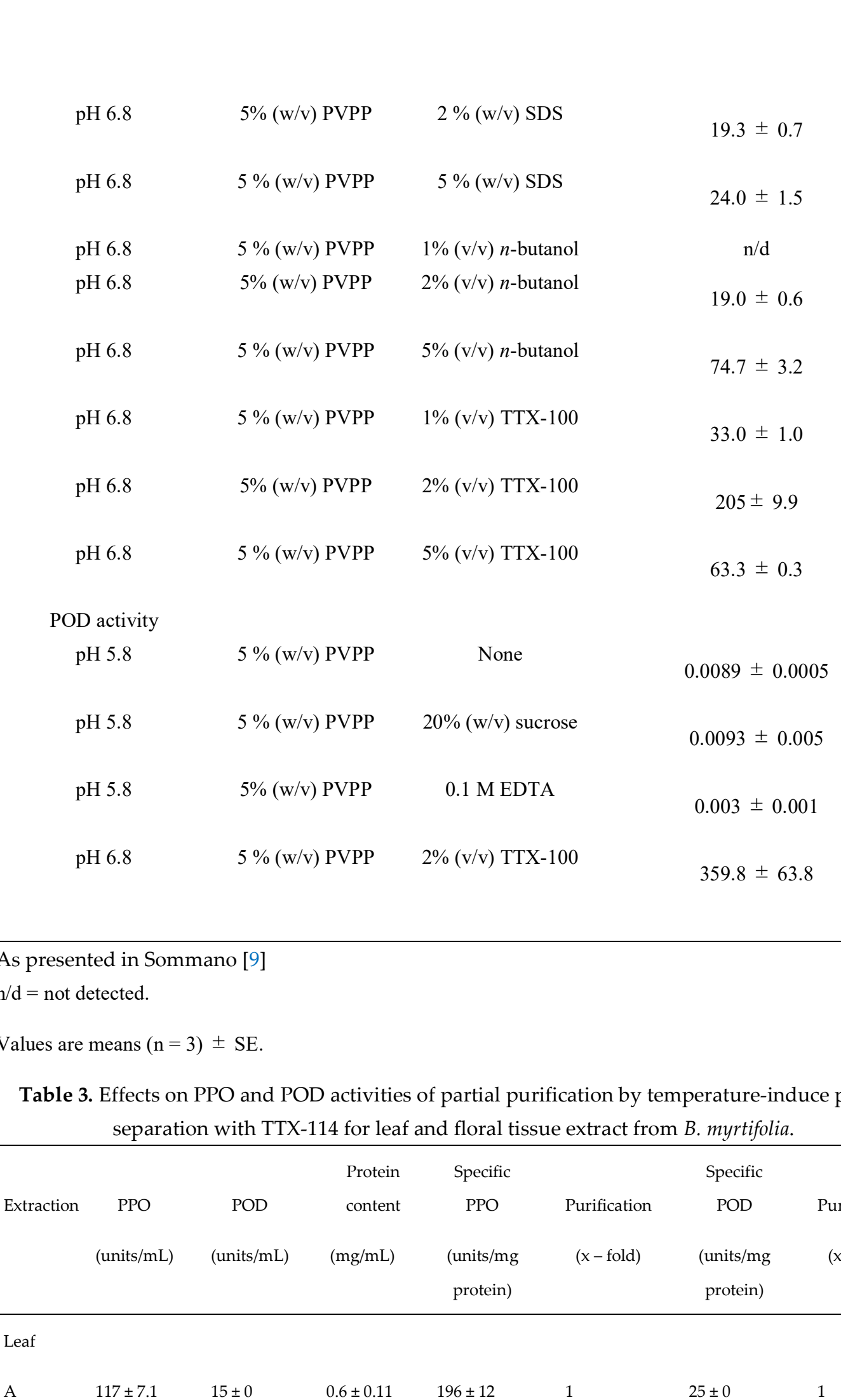

As presented in Sommano [9]

$\mathrm{n} / \mathrm{d}=$ not detected.

Values are means $(n=3) \pm S E$.

Table 3. Effects on PPO and POD activities of partial purification by temperature-induce phase separation with TTX-114 for leaf and floral tissue extract from B. myrtifolia.

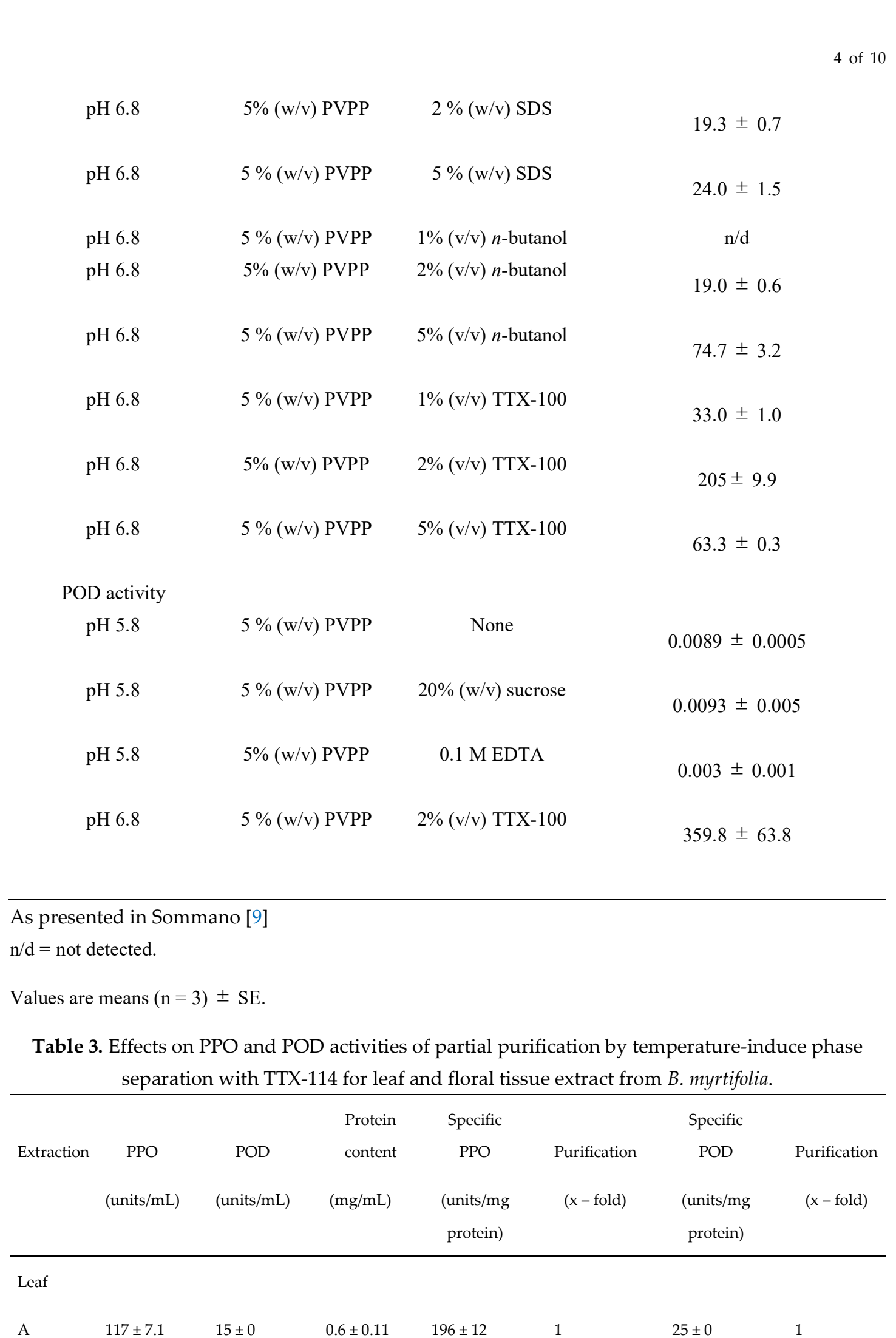

Leaf

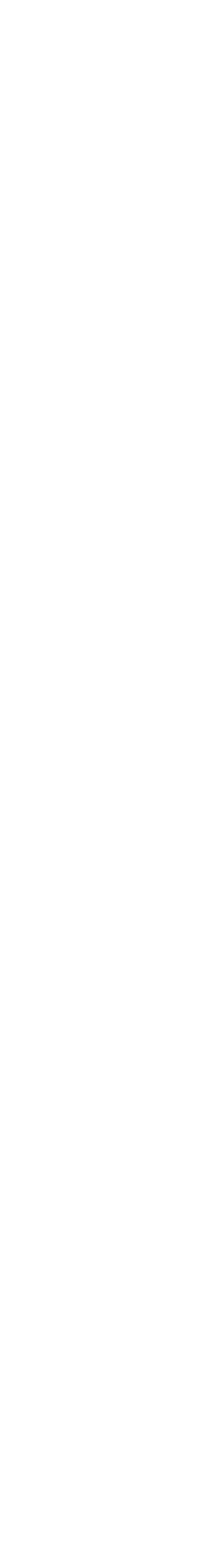

$\begin{array}{lllllll}343 \pm 24 & 78 \pm 0.3 & 0.75 \pm & 460 \pm 32 & 2.5 & 107 \pm 0.4 & 4.3\end{array}$

B

0.14

C

$182 \pm 8.2 \quad 88 \pm 35$

$1.8 \pm 0.29 \quad 101 \pm 4.5$

0.5

$48.4 \pm 19.0 \quad 2.4$ 
Flower

\begin{tabular}{|c|c|c|c|c|c|c|}
\hline A & $\mathrm{n} / \mathrm{a}$ & $\mathrm{n} / \mathrm{a}$ & $\begin{array}{l}0.48 \pm \\
0.12\end{array}$ & $\mathrm{n} / \mathrm{a}$ & 1 & 0 \\
\hline B & $73 \pm 1.8$ & $8.9 \pm 1.1$ & $\begin{array}{l}0.23 \pm \\
0.03\end{array}$ & $319 \pm 7.8$ & 300 & $39 \pm 4.7$ \\
\hline C & $103 \pm 25$ & $22 \pm 3.9$ & $\begin{array}{l}0.56 \pm \\
0.01\end{array}$ & $183 \pm 45$ & 200 & $39 \pm 7.0$ \\
\hline
\end{tabular}

As presented in Sommano [9]

$\mathrm{n} / \mathrm{a}=$ no activity.

Values are means $(n=3) \pm S E$.

$\mathrm{A}=$ Crude enzyme extract with 5\% PVPP and 2\% TTX-114 in sodium phosphate buffer.

$\mathrm{B}=$ Crude extract $(\mathrm{A})$ subjected to temperature induced phase separation with $8 \%$ TTX-114.

$\mathrm{C}=$ Concentrated protein of extract $(\mathrm{B})$ by an Amicon ${ }^{\circledR}$ filter unit (AFU).

Upon staining in $0.1 \mathrm{M}$ catechol solution for PPO activity, a single activity band was found in each lane for crude leaf, crude freeze-dried leaf and crude flower extracts (Figure 1. a). However, no activity was present for the freeze-dried extract of floral tissue. No POD activity band was detected in the same gel post-stained in a $100 \mathrm{mM} \mathrm{H} \mathrm{O}_{2}$ solution (Figure 1. b). Phenols and chlorophylls were evident in the lanes as greenish-brown pigments. Enzyme activities of crude and concentrated protein extracts (AFU retentate) were also compared on Native PAGE (Figure 2.). No POD activity band was detected in any extracts, even with concentration through the AFU (data not shown). 
6 of 10

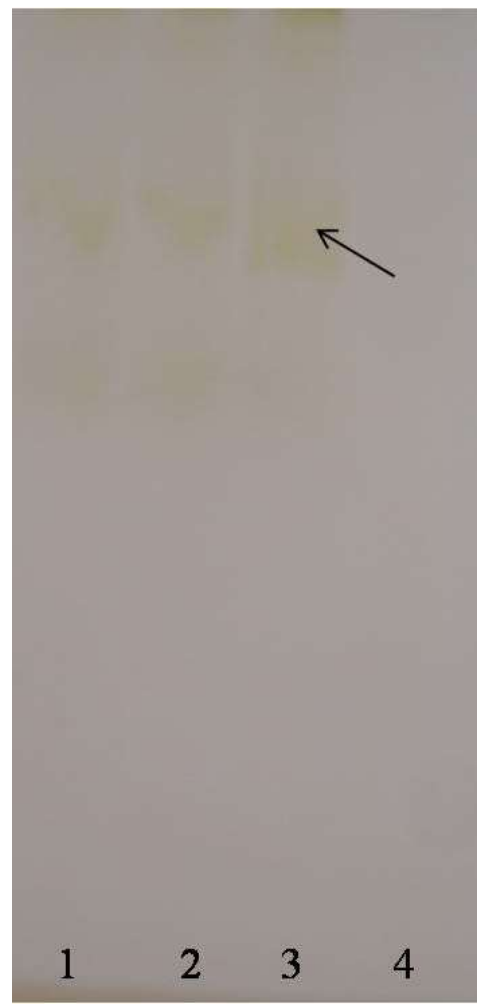

(a)

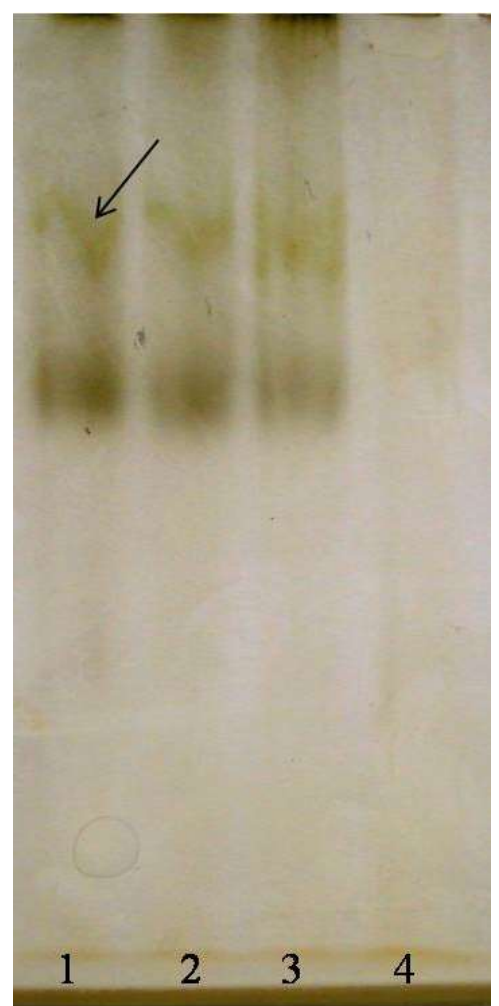

(b)

Figure 1. Native PAGE analysis for crude B. myrtifolia leaf and flower extracts with staining for PPO activity (a) and POD activity (b): Lane 1, fresh leaf extract (protein $=9.4 \mu \mathrm{g}$ ); lane 2, freeze dried leaf extract (protein $=11.4 \mu \mathrm{g}$ ); lane 3, fresh flower extract (protein $=9.7 \mu \mathrm{g}$ ); and, lane 4 , freeze dried flower extract (protein $=10 \mu \mathrm{g}$ ) [9]. Arrows indicate chlorophyll (interference). 


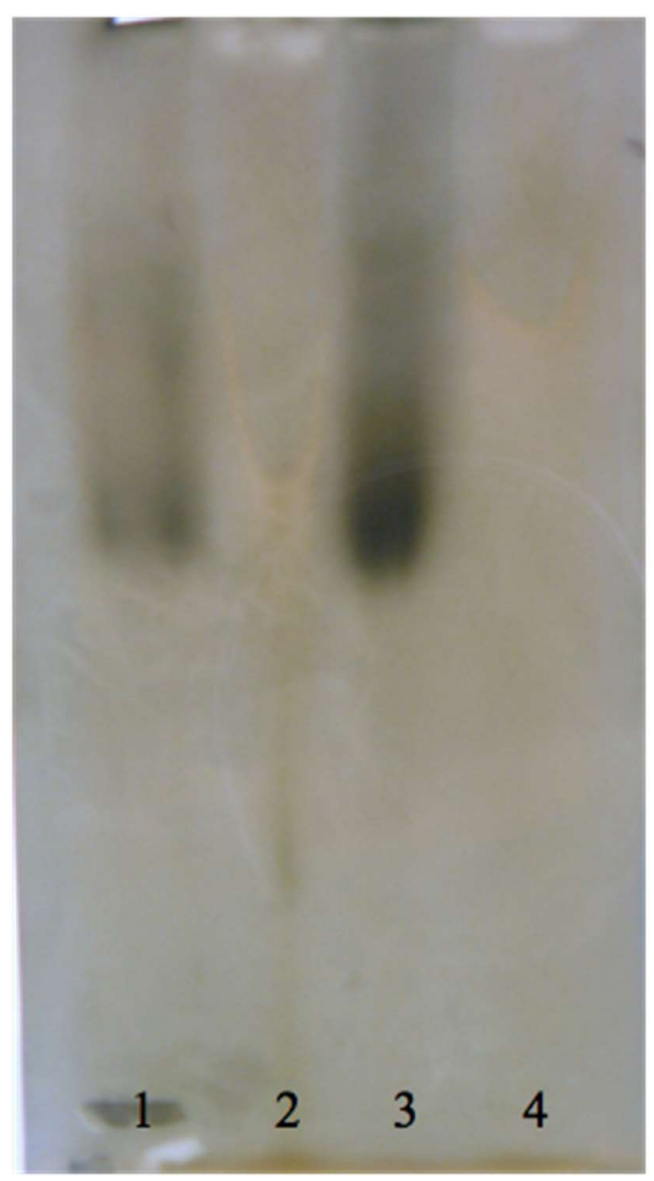

Figure 2. Native PAGE analysis comparison of crude extract and concentrated protein extract for $B$. myrtifolia leaves and flowers obtained using an Amicon ${ }^{\circledR P L}-10$ unit (AFU) and upon staining for PPO activity: Lane 1, fresh leaf extract (protein = 37.4 $\mu \mathrm{g}$ ); lane 2, fresh flower extract (protein = 27.2 $\mu \mathrm{g}$ ); lane 3, concentrated leaf extract (protein = $52.8 \mu \mathrm{g}$ ); and, lane 4, concentrated flower extract (protein $=30.5 \mu \mathrm{g})$.

\section{Conclusion}

In studying PPO and POD in plant phenolic rich like B. myrtifolia tissues, a combination of PVPP and high temperature-induced phase separation effectively improved enzymatic activity, including activity bands on native electrophoresis.

Funding: This was part of research financially supported by School of Agriculture and Food Sciences, The University of Queensland, Australia (Prof. D. Joyce and Dr. B. D'Arcy).

Acknowledgments: The author also thank the School of Agriculture, Food and Wine at the University of Adelaide's Waite Campus (Dr. A. Able) and BSES Limited (Dr. P Joyce) for hosting part of the work describe herein.

Conflicts of Interest: The authors declare no conflict of interest.

\section{References}

1. Eyre, J.X.; Joyce, D.C.; Irving, D.E. Post-harvest browning syndrome and other qualities and defects in Backhousia myrtifolia. Journal of Horticultural Science and Biotechnolology. 2011, 86, 225-229. 
2. Sommano, S.; Joyce, D.C.; Dinh, S.Q.; D'Arcy, B. Alternaria alternata causes pre-harvest discolouration in Backhousia myrtifolia leaf. Australasian Plant Disease Notes. 2011, 6, 64-66.

3. Sommano, S.; Joyce, D.C.; Dinh, S.Q.; D'Arcy, B. Infection by Alternaria alternata caused discolouration of Backhousia myrtifolia foliage and flowers. Journal of Horticultural Science and Bioltechnology. 2012, 87(1), 41-46.

4. Lim-Camacho, L. Australian native flowers in the Japanese market. A compendium of market research. Gatton: Centre for Native Floriculture. The University of Queensland. 2006.

5. Lim-Camacho, L.; Dunne, T.; Firrell, C. The Backhousia Project: a value chain alliance for Australian native cut flower to Japan. Acta Horticulturae. 2006, 699, 269-276.

6. Pourcel, L.; Routaboul, J.M.; Cheynier, V.; Lepiniec, L.; Debeaujon, I. Flavonoid oxidation in plants: from biochemical properties to physiological functions. Trends in Plant Science. 2007, 12(1), 29-36.

7. Whitaker, J.R.; Lee, C.Y. Enzymatic browning and its prevention. Washington, DC: American Chemical Society. 1995.

8. Whitaker J.R.; Lee, C.Y. Chemistry of enzymatic browning. Washington D.C.: American Chemical Society. 1995, 338 p.

9. Sommano, S. Extraction of active polyphenol oxidase and peroxidase from a plant rich in phenolics: Backhousia myrtifolia. Acta Horticulturea. 2015a, 1088, 547 -551.

10. Sommano, S. Physiological and biochemical changes during heat stress induced browning of detached Backhousia myrtifolia (Cinnamon Myrtle) Tissues. Tropical Plant Biolology. 2015b, 8, 31-39.

11. Sommano S.; Kumpoun W.; Yusuf N.A. Subcellular extraction and enzyme characterisation of polyphenol oxidase and peroxidase in Cinnamon myrtle. Acta Physiologiae Plantarum.

2017, 39, 36.

12. Gauillard, F.; Forget, F. R. Polyphenol oxidases from Williams pear (Pyrus communis L, cv Williams): activation, purification and some properties. Journal of the Science of Food and Agriculture. 2009, 74(1), 49-56.

13. Jukanti, A.K.; Bruckner, P.L; Habernicht, D. K.; Foster, C.R.; Martin, J.M.; Fischer, A.M. Extraction and activation of wheat polyphenol oxidase by detergents: biochemistry and applications. Cereal Chemistry, 2003, 80(6), 712-716.

14. Okot-Kotber, M.; Liavoga, A.; Yong, K.J.; Bagorogoza, K. Activation of polyphenol oxidase in extracts of bran from several wheat (Triticum aestivum) cultivars using organic solvents, detergents, and chaotropes. Journal of Agricultural and Food Chemistry. 2002, 50(8), 2410-2417.

15. Sanchez-Ferrer, A.; Bru, R.; Garciacarmona, F. Novel procedure for extraction of a latent grape polyphenol oxidase using temperature-induced phase-separation in Triton X-114. Plant Physiology. 1989, 91(4), 1481-1487.

16. Sanchez-Ferrer, A.; Villalba, J.; García-Carmona, F. Triton X-114 as a tool for purifying spinach polyphenol oxidase. Phytochemistry. 1989, 28(5), 1321-1325.

17. Bradford, M.M. Rapid and sensitive method for quantitation of microgram quantities of protein utilizing principle of proein-dye binding. Analytical Biochemistry. 1976, 72(1-2), 248254. 
9 of 10

18. Jiang, Y.M. Purification and some properties of polyphenol oxidase of longan fruit. Food Chemistry. 1999, 66(1), 75-79.

19. Yang, Y.; Wang, Z. Some properties of polyphenol oxidase from lily. International Journal of Food Science and Technology. 2008, 43(1), 102-107.

20. Dann, E.K.; Deverall, B.J. Activation of systemic disease resistance in pea by an avirulent bacterium or a benzothiadiazole, but not by a fungal leaf spot pathogen. Plant Pathology. 2000, 49(3), 324-332.

21. Sergio, L.; Cardinali; A.; De Paola, A.; Di Venere, D. Biochemical properties of soluble and bound peroxidases from artichoke heads and leaves. Food Technology and Biotechnology.

2009, 47(1), 32-38.

22. Hadaway, T.; March, T.; Able, A.J. The involvement of peroxidases in the formation of black point in barley. 12th Australian Barley Technical Symposium Conference Proceedings: Australian Barley Association. 2005, pp. 185-188.

23. Liu, C.J.; Chao, S.; Gale, M.D. The genetical control of tissue-specific peroxidases Per-1, Per2, Per-3, Per-4 and Per-5 in wheat. Theoretical and Applied Genetics. 1990, 79(3), 305-313. 